\title{
PENERAPAN KONSELING KELOMPOK TEKNIK SEFT UNTUK MEREDUKSI KEJENUHAN BELAJAR SISWA KELAS VIII SMP SUNAN GIRI MENGANTI
}

\author{
Pury Ayu Fitriya $\mathbf{S}^{1}$, Elia Firda Mufida ${ }^{2}$, \\ 1.2Universitas PGRI Adi Buana Surabaya, Jl. Dukuh Menanggal XII \\ Email: puryayufitriya@gmail.com
}

\begin{abstract}
Pandemi covid 19 yang terjadi dikala ini mengakibatkan dunia pendidikan khusunya proses pembelajaran di semua sekolah yang di lakukan secara daring, di mana sebelumnya siswa dapat melakukan proses pembelajaran secara langsung dan dapat berinteraksi dengan teman-teman, guru, serta semua yang ada di lingkungan sekolah, akibat pandemi covid 19 pembelajaran yang dilakukan secara daring memberikan dampak terhadap kejenuhan belajar pada siswa, tata cara pembelajaran (Daring) jarak jauh membuat siswa membutuhkan waktu dalam menyesuaikan diri dalam mengalami proses pembelajaran baru yang secara tidak langsung mempengaruhi tenaga serap belajar siswa hal ini bisa memicu munculnya kejenuhan belajar siswa. Tujuan penelitian ini adalah untuk mengetahui pengaruh penerapan teknik seft dalam mengurangi kebosanan belajar pada siswa kelas VIII SMP. Penelitian ini menggunakan pendekatan kuantitatif yang menggunakan jenis penelitian pra eksperimen dengan menggunakan One Group Pre-Test Post-Test Design.Penelitian ini terdiri dari dua variabel yaitu variabel X (Teknik SEFT dalam Konseling Kelompok) dan variabel Y (Kejenuhan Belajar). Populasi dalam penelitian ini adalah siswa kelas VIII A dan B SMP Sunan Giri Menganti yang berjumlah 63 siswa, sampel diambil dengan teknik purposing sampling dan diperoleh 4 Data yang terkumpul kemudian dianalisis menggunakan uji Wilxocon menggunakan SPSS for Windows versi 26.
\end{abstract}

Keywords: Teknik SEFT, kejenuhan belajar, konseling kelompok

\section{INTRODUCTION}

Pandemi covid 19 yang terjadi dikala ini mengakibatkan dunia pendidikan khusunya proses pembelajaran di semua sekolah yang di lakukan secara daring, di mana sebelumnya siswa dapat melakukan proses pembelajaran secara langsung dan dapat berinteraksi dengan teman-teman, guru, serta semua yang ada di lingkungan sekolah, akibat pandemi covid 19 pembelajaran yang dilakukan secara daring memberikan dampak terhadap kejenuhan belajar pada siswa, tata cara pembelajaran (Daring) jarak jauh membuat siswa membutuhkan waktu dalam menyesuaikan diri dalam mengalami proses pembelajaran baru yang secara tidak langsung mempengaruhi tenaga serap belajar siswa hal ini bisa memicu munculnya kejenuhan belajar siswa. Jika seorang siswa telah menghadapi kejenuhan dikala belajar hingga para siswa sulit berkonsentrasi dalam menjajaki pendidikan. Kegiatan belajar yang dicoba di masa pandemi covid 19 memanglah tidak dapat dikatakan wajar sebab guru tidak dapat melaksanakan tugasnya dengan semestinya. Para siswa merasa pendidikan yang dicoba secara daring dialami sangat 
menjenuhkan, karena siswa yang sudah terbiasa berinteraksi di sekolah mulai merasa kesepian ketika belajar dari rumah dan sulitnya berkonsentrasi ketika mengerjakan tugas yang diberikanoleh guru, sulitnya memahami materi yang diberikan guru melalui link video youtube atau ppt yang dibagikan melalui google classroom, beberapa siswa mengatakan tidak dapat memahami materi/tugas yang diberikan oleh guru.

Menurut Suwarjo \& Diana S, (2014). Mengartikan kejenuhan (burnout) selaku sesuatu kondisi keletihan( exhaustion) raga, emosional, serta mental. Sedangkan menurut Pines \& Aronson, (2001) kejenuhan ialah kondisi emosional pada diri orang dikala merasa keletihan dan jenuh secara raga ataupun mental akibat dari banyaknya tekanan pada pekerjaan yang terus menjadi bertambah. Thursan Hakim, (2004) bahwa kejenuhan belajar merupakan sesuatu keadaan mental seorang dikala menghadapi rasa bosan serta letih yang amat sangat sehingga menyebabkan munculnya rasa jenuh, lesu, tidak bergairah melaksanakan kegiatan belajar. Dari komentar para pakar di atas hingga bisa disimpulkan bahawa kejenuhan dalam belajar ialah kondisi emosi yang terdapat pada diri orang dikala telah merasa letih dan merasa jenuh secara raga ataupun mental dari banyaknya beban tugas yang didapatkan menjadi penyebab sseorang mengalami rasa bosan yang menimbulkan rasa malas melakukan kegiatan belajar. bagi para siswa yang hanya belajar dirumah saja setiap harinya, keadaan ini membuat siswa mengalami emosi yang berubah-ubah karena banyaknya tuntutan tugas yang didapatkan dari sekolah, kejenuhan dalam belajar yang banyak dirasakan oleh siswa akibat pembajaran daring ini jika tidak mendapat penanganan yang baik akan membuat siswa kehilangan motivasi belajar, menurunya prestasi belajar, dan sulit mengendalikan emosi. SEFT( spiritual emotional freedom technique) yakni tata cara penyembuhan yang memadukan keampuhan tenaga psikologi dengan doa serta spiritualitas. Tenaga psikologis merupakan ilmu yang mempraktikkan bermacam prinsip serta metode bersumber pada konsep sistem tenaga badan dalam membetulkan keadaan fikiran, emosi serta sikap seorang.

Zainudin, (2006) menjelaskan pengobatan terapi SEFT (spiritual emotional freedom technique) ialah terapi pengobatan dengan memakai gerakan simpel yang dicoba buat menolong menuntaskan permasalahan kasus sakit raga ataupun psikis, tingkatkan kinerja serta prestasi, mencapai kedamaian serta prestasi dan kebermaknaan hidup. Kejunuhan merupakan kondisi emosi dan SEFT berhubungan dengan pengelolaan emosi yang menggabungkan sistem energi tubuh dan spiritual yang dapat mengatasi masalah emosional dan fisik, maka kedua hal tersebut dapat digabungkan. Melihat dari latar belakang di atas maka peniliti melaksanakan riset konseling kelompok dengan memakai terapi pengobatan SEFT( spiritual emotional freedom technique), untuk mereduksi kejenuhan belajar pada siswa selama proses pembelajaran yang dilakukan secara daring akibat covid-19. 


\section{METHOD}

Metode penelitian studi ini memakai pendekatan kuantitatif dengan mengenakan desain one group pre test dan post test, desain ini dapat ditafsirkan sebagai berikut:

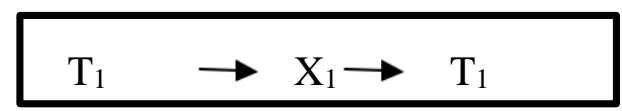

\section{Keterangan :}

$\mathrm{T}_{1}$ : $\quad$ Pre-test digunakan untuk mengukur perilaku konseli sebelum diberikan treatmean layanan konseling kelompok dengan memakai terapi SEFT.

$\mathrm{X}_{\mathrm{t}}$ : $\quad$ Perlakuan atau treatment (pemberian layanan konseling kelompok dengan memakai mode terapi $S E F T$ ).

$\mathrm{T}_{2}$ : $\quad$ Post-test dibuat untuk mengukur sikap konseli sehabis diberikan layanan konseling kelompok memakai metode terapi SEFT.

Populasi dalam riset merupakan para siswa kelas VIII SMP Sunan Giri Menganti sebanyak 63 orang siswa, Periset memilah ilustrasi dengan mengenakan purposive sampling karena tidak segala ilustrasi memiliki kriteria sesuai dengan yang telah pengamat tentukan. Oleh karena itu, ilustrasi yang dipilih terencana ditentukan bersumber pada kriteria yang sudah ditetapkan oleh periset memakai perlengkapan pengumpulan informasi berbentuk angket yang disusun bersumber pada penanda kejenuhan belajar, dimana responden dimohon buat mengisi angket yang telah disediakan buat memastikan tingkatan kejenuhan belajar, dari 63 populasi diseleksi 4 siswa yang menghadapi tingkatan kejenuhan belajar sangat besar.

Teknik metode analisis data ialah metode yang dicoba untuk menganalisis data dengan tujuan supaya bisa menanggapi rumusan permasalahan. Apabila sudah terkumpul data yang dibutuhkan dalam riset, buat mendapatkan hasil informasi yang diolah terlebih dulu lewat analisis data. Analisis data dicoba dengan uji wilcoxon memakai aplikasi SPSS tipe 26.

\section{RESULT}

Hasil penelitian ini akan menyajikan data yang diperoleh setelah pre-test, yang akan menentukan jumlah subjek yang akan mendapatkan perlakuan. Dalam penelitian ini skala penelitian untuk mengukur kejenuhan belajar siswa menggunakan 1 sampai dengan 4 butir pernyataan termasuk 55 pernyataan, sehingga dapat ditentukan interval baku sebagai berikut: 


\section{$\frac{\text { Skor tertinggi - skala terendah }}{4}$}

Maka, untuk menentukan 4 kategori tersebut adalah:

$117-48$
4

$17,25=17$

\begin{tabular}{|l|l|l|}
\hline $100-117$ & $=$ & Sangat tinggi \\
\hline $82-99$ & $=$ & Tinggi \\
$64-81$ & $=$ & Rendah \\
\hline $46-63$ & $=$ & Sangat Rendah \\
\hline
\end{tabular}

Penelitian ini dilakukan dengan menyebarkan pertanyaan atau angket kepada 63 peserta kelas VIII A serta VIII B di SMP Sunan Giri Menganti. Para siswa mengisi setiap butir pertanyaan sesuai dengan dirinya dan hasil dari angket tersebut dikategorikan menjadi beberapa tingkatan yaitu sangat tinggi, tinggi, sedang dan rendah pada masalah kedisiplinan belajar mereka. Dari hasil instrumen angket tersebut didapatkan 4 siswa yang mempunyai nilai kejenuhan belajar tinggi yang akan dipilih peneliti menjadi responden dalam konseling kelompok. Berikut adalah hasil pre test terendah dari kelas VIII A serta VIII B SMP Sunan Giri Menganti.

\begin{tabular}{lccc}
\hline No & Responden & Total & Kategori \\
\hline $\mathbf{1}$ & NPR & 117 & Sangat Tinggi \\
$\mathbf{2}$ & ANS & 116 & Sangat Tinggi \\
$\mathbf{3}$ & AW & 113 & Sangat Tinggi \\
$\mathbf{4}$ & KYA & 116 & Sangat Tinggi \\
\hline
\end{tabular}

Tabel 1. Hasil pre-test tertinggi kelas VIII A serta VIII B SMP Sunan Giri Menganti

Berdasarkan hasil tabel diatas peneliti dapat menentukan jumlah responden sebanyak 4 siswa yang mempunyai tingkat kejenuhan belajar yang tinggi. Setelah menentukan jumlah responden yang telah dipilih peneliti memberikan perlakuan yaitu pemberian treatmean layanan konseling kelompok dengan menggunakan terapi Seft untuk mereduksi kejenuhan belajar siswa sebanyak 6 kali traetmean. Berikut adalah paparan terkait dengan pelaksanaan konseling kelompok dengan terapi SEFT untuk mereduksi kejenuhan belajar siswa.

\section{DISCUSSION}

Pada pertemuan awal konselor membangun ikatan baik antara Konselor dengan anggota konseling kelompok serta membahastentang permasalahan kejenuhan belajar yang dialami siswa di masa pandemi.. Pada pertemuan kedua Mereview pertemuan konseling pertama tentang apa saja penyebab siswa mengalami kejenuhan belajar selama pembelajaran daring, konselor memberikan penjelasan tentang teknik seft itu seperti apa dan bagaimana 
caranya untuk membantu dalam mengatasi kejenuhan belajar pada siswa. Pertemuan ketiga mereview pertemuan kedua, dipertemuan ketiga ini siswa mulai diberikan pekerjaan rumah oleh konselor untuk mempraktikan teknik seft untuk dapat menanggulangi permasalahan kejenuhan belajar yang dirasakan oleh siswa. Pertemuan keempat membahas tentang pekerjaan rumah yang sudah diberikan oleh konselor, tugas yang dilakukan secara mandiri oleh siswa, kemudian konselor akan mereview bagaimana perasaan siswa sebelum dan setelah melaksanakan treatmean yang sudah dilakukan secara mandiri dirumah masing-masing. Pertemuan kelima Pertemuan kelima siswa diberikan angket kejenuhan belajar untuk membandingkan tingkat kejenuhan belajar sebelum dan sesudah diberikan treatmean oleh konselor. Pertemuan keenam atau terakhir evaluasi dari hasil treatment dari awal sampai akhir pertemuan. Dari hasil konseling kelompok dengan menggunakan teknik Seft tersebut siswa mampu mereduksi tingkat kejenuhan belajar. Berikut hasil post-test dari kelas VIII A serta VIII B SMP Sunan Giri Menganti:

\begin{tabular}{cccc}
\hline No & Respoden & $\begin{array}{c}\text { Post- } \\
\text { test }\end{array}$ & $\begin{array}{c}\text { Tingkat } \\
\text { Kejenuhan }\end{array}$ \\
\hline $\mathbf{1}$ & NPR & 97 & Tinggi \\
$\mathbf{2}$ & ANS & 96 & Tinggi \\
3 & AW & 93 & Tinggi \\
4 & KYA & 96 & Tinggi \\
\hline
\end{tabular}

Tabel 2. Hasil post-test kejenuhan belajar siswa kelas VIII A serta B SMP Sunan Giri Menganti

Pada tabel 2 menunjukkan bahwa setiap responden mengalami penurunan kejenuhan belajar pada setiap individu. Hasil dari post-test yang telah diberikan kepada 4 responden penelitian masing-masing individu mengalami penurunan kejenuhan belajar. Hasil dari penerapan konseling kelompok teknik Seft untuk mereduksi kejenuhan belajar siswa kelas VIII SMP Sunan Giri Menganti. Pada tabel dibawah menunjukkan bahwa setiap responden mengalami penurunan kejenuhan dalam belajar. Hasil dari post-test yang telah diberikan kepada 4 responden penelitian masing-masing individu mengalami penurunan kejenuhan belajar. Hal itu akan dijelaskan peneliti sebagai berikut: 

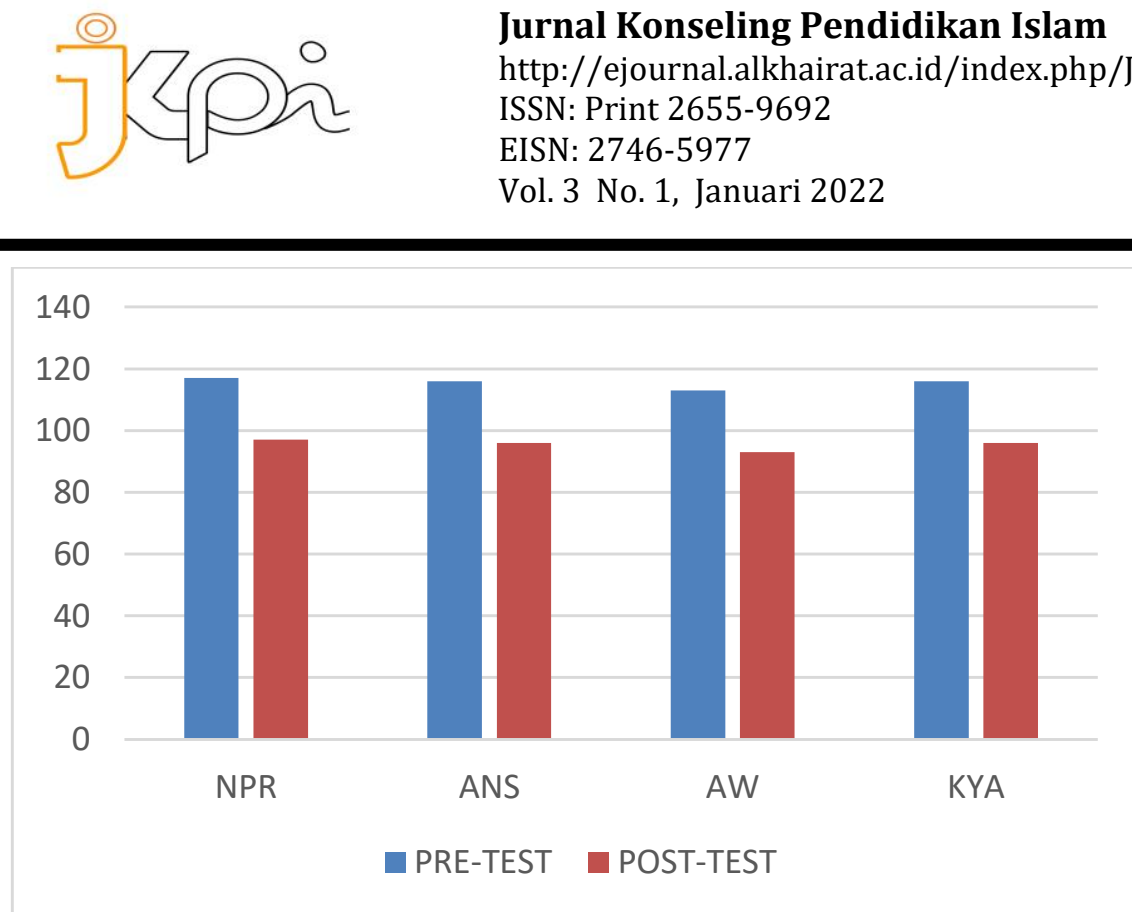

Tabel 3.Grafik hasil Pre-test dan Post-test

Didasarkan Pada penelitian ini, analisis yang digunakan adalah teknik analisis non-parametrik dengan menggunakan metode uji Wilcoxon. Karena sampel yang diambil relatif kecil, dan menganalisis hasil-hasil pengamatan yang berpasangan dari 2 data apakah terdapat perubahan atau tidak. Manfaat dari hasil test dalam penelitian ini adalah untuk menentukan ada atau tidaknya pengaruh yang ditimbulkan sebelum dan sesudah diberikan terapi seft. Hasil uji wilcoxon sebagai berikut:

\begin{tabular}{llr|r|r} 
& \multicolumn{2}{c}{ Ranks } & & \\
& & $\mathrm{N}$ & Mean Rank & Sum of Ranks \\
\hline POST TES - PRE TEST & Negative Ranks & $4^{\mathrm{a}}$ & 2.50 & 10.00 \\
\cline { 2 - 5 } & Positive Ranks & $0^{\mathrm{b}}$ & .00 & .00 \\
\cline { 2 - 5 } & Ties & $0^{\mathrm{c}}$ & & \\
\cline { 2 - 5 } & Total & 4 & & \\
\hline
\end{tabular}

a. POST TES < PRE TEST

b. POST TES $>$ PRE TEST

c. POST TES $=$ PRE TEST

\begin{tabular}{|l|r|}
\hline \multicolumn{2}{|c|}{ Test Statistics $^{\mathrm{a}}$} \\
\hline & $\begin{array}{c}\text { Posttest - } \\
\text { Pretast }\end{array}$ \\
\hline Z & $-2.000^{\mathrm{b}}$ \\
\hline Asymp. Sig. (2-tailed) & .046 \\
\hline
\end{tabular}

a. Wilcoxon Signed Ranks Test

b. Based on negative ranks.

Negatif Rank atau selisih (negatif) kejenuhan belajar untuk pre-test dan post-test. Di sini terdapat 0 data negatif $(\mathrm{N})$ Hasil interpretasi data ini menggunakan uji wilcoxon adalah sebagai berikut.

1. Negatif Rank atau selisih (negatif) antara perilaku konsumtif mahasiswa untuk pre-test dan post-test. Di sini terdapat 0 data negatif $(\mathrm{N})$ maksudnya 
ke 4 siswa hadapi penyusutan dalam kejenuhan belajar dari nilai pre- test ke nilai post- test. Mean rank ataupun rata- rata penyusutan tersebut merupakan 0 sebaliknya jumlah rangking ataupun sum of rank merupakan 0

2. Positif Ranks atau selisih (positif) antara kejenuhanbelajar untuk pre-test ke post-test. Di sini terdapat 4 data positif (N) yang artinya ada 4 informasi positif( N) yang maksudnya ke 4 siswa hadapi kenaikan kejenuhan belajar dari nilai pre- test ke nilai post- test. Mean Rank ataupun rata- rata kenaikan tersebut merupakan sebesar 2. 50, sebaliknya jumlah ranking postif ataupun sum of ranks merupakan sebesar 10. 00 .

3. Ties ialah kesamaan nilai pre- test serta post- test. Pada nilai Ties merupakan 0 , sehingga bisa dikatakan kalau tidak terdapat nilai yang sama antara pre- test serta post- test.

Berdasarkan hasil analisis uji wilcoxon pada tabel test statistics diatas diketahui Asymp. Sig( 2- tailed) bernilai 0, 046. Sebab nilai 0, 046 lebih kecil dari\&lt; 0, 05, hingga bisa disimpulkan kalau Ha diterima. Maksudnya terdapat perbandingan antara kejenuhan belajar siswa saat sebelum pre- test serta setelah post- test, sehingga bisa disimpulkan kalau terdapat penyusutan kejenuhan belajar dengan memakai konseling kelompok metode Seft buat siswa kelas VIII SMP Sunan Giri Menganti.

\section{CONCLUSION}

Bersumber pada hasil riset yang sudah dicoba serta ulasan riset menimpa pelaksanaan konseling kelompok metode Seft untuk mereduksi kejenuhan belajar bisa disimpulkan bahwa kejenuhan belajar pada siswa kelas VIII A serta VIII B SMP Sunan Giri Menganti sehabis diberikan treatmean hadapi penyusutan yang signifikan, Penyusutan kejenuhan belajar bisa dilihat dari nilai skor rata- rata, perihal tersebut dilihat dari sesi Pretest sampai Postest. Hasil tersebut antara lain: Rata- rata skor pada Pre-test serta Rata- rata skor Post-test. Maka dapat disimpulkan bahwa kejenuhan belajar pada siswa kelasVIII SMP Sunan Giri Menganti, sebelum diberikan layanan konseling kelompok teknik Seft tingkat kejenuhan belajar yang dialami 4 siswa kelas VIII SMP dikategorikan memiliki tingkat kejenuhan belajar yang sangat tingi setelah diberikan treatmean 4 siswa tersebut mengalami penurunan yang signifikan, berdasarkan hasil Uji Wilcoxon dan didapatkan hail 0,046, karena $0,046<$ dari 0,05 yang dapat diartikan bahwa hipotesis diterima, maka penerapan konseling kelompok teknik Seft dapat menurunkan tingkat kejenuhan belajar siswa.

Berdasarkan kesimpulan hasil penelitian yang telah dikemukakan diatas, maka dapat diajukan beberapa saran sebagai berikut, bagi guru bimbingan dan konseling dapat menjadi bahan untuk dipelajari agar Ketika mendapat siswa yang memiliki tanda-tanda kejenuhan belajar dapat memberikan Teknik seft kepada siswa sebagai salah satu cara untuk mengatasi kejenuhan belajar dan permasalahan lainnya menggunakan Teknik seft.

Bagi peneliti selanjutnya hasil ini diharapkan bisa digunakan sebagai bahan acuan bagi peneliti lain yang tertarik untuk memperkuat penelitian ini, dapat melakukan penelitian dalam jenjang pendidikan yang berbeda selain 
SMP, jenis layanan yang berbeda, dan strategi yang berbeda selain dengan teknik Seft sehingga akan diperoleh wawasan tambahan.

\section{BIBLIOGRAPHY}

Hakim, Tursam. 2004. Belajar Secara Efektif. Jakarta: Puspa Swara.

Pawicara, R., Conilie, M. 2020. "Analisis pembelajaran daring terhadap kejenuhan belajar mahasiswa Tadris Biologi IAIN Jember di tengah pandemi Covid-19”. ALVEOLI: Jurnal Pendidikan Biologi. Vol. 1. No.1. 29-38.

Pines, A and Aronson, El. 2002. Career Bournout: Causes and Cures, New York: The Free Press, A Division of Macmillan.Inc.

Rinawati, D, Darisman, E. K. 2020. "Survei tingkat kejenuhan siswa SMK belajar di rumah pada mata pelajaran produk kreatif dan kewirausahaan selama masa pandemi covid-19". Journal of Science and Education (JSE). Vol. 1. No.1. 32-40.

Sugiyono. 2018. Metode Penelitian Kuantitatif. Bandung: Alfabeta

Suryabrata, Sumadi. 2014. Metodologi Penelitian. Jakarta: Rajawali Pers Suwarjo, Purnama. 2014. Model Bimbingan Pengembangan Kompetensi Pribadi Sosial Bagi Siswa SMA yang Mengalami Kejenuhan Belajar (Burnout). Laporan Penelitian. FIP UNY.

Zainuddin, Ahmad Faiz. 2010. SEFT (Spiritual Emotional Freedom Technique). Jakarta: PT. Arga Publishing.

Zainuddin, Ahmad Faiz. 2012. SEFT (Spiritual Emotional Freedom Technique). Jakarta:Afzan Publishing https://www.kompasiana.com/tengkuemalia/kejenuhan-belajar-siswa-padamasa-pandemi. Diakses/diunduh, 24 Januari 2021 pukul 18.00. 